\title{
A case of pediatric AIDS in Dr. Sutomo Hospital Surabaya, Indonesia
}

\author{
Ismoedijanto, Rosanti Yustina, Rahayu Tri Lestari, Hidayat Burhan
}

Departement of Child Health, Medical School, Airlangga University, Surabaya

\begin{abstract}
We report a 2-year old girl who suffered from HIV. The diagnosis was based on history, clinical findings, and laboratory work-up. Suspicion of the presence of HIV was started when the girl continued to have wasting syndrom e with several focal infections unresponsice to ordinary treatment. The patient past away following severe diarrhea and apparently sepsis. [Paediatr Indones 2001; 41:121-124]
\end{abstract}

Keywords: acquired immune deficiency syndrome, children, wasting syndrome

AIDS (acquired immune deficiency syndrome) was first reported in USA among children in the year of 1982 and by the end of 2000 the total number of cases in children was estimated to be 5-8 million worldwide. AIDS had become the $9^{\text {th }}$ leading cause of death in USA and a real threat to the people in Africa. ${ }^{1-3}$

In East Java AIDS was first recognized in 1989, 11 years after AIDS had been declared as a world epidemic. During the year of 1995 there were reports of two mothers with HIV, one baby was serologically negative at the age more than 18 months and did not developing any clinical signs of AIDS. Up to December 2000 there are 174 cases of HIV infection, with two cases of pediatric AIDS. The first case was diagnosed during hospitalization and the other died in a health center. ${ }^{4}$

Pediatric AIDS posed many clinical problems, one is the diagnosis of the HIV infection and especially on diagnosis of combined infectious complica-

Correspondence: Ismoedijanto, M.D., Department of Child Health, Medical School, Airlangga Univerity - Soetomo Hospital, Surabaya, Indonesia. tions and their treatment. ${ }^{5,6}$ Each patient must be assessed clinically and immunologically. In time of economic crisis in Indonesia, the ability and availability of diagnostic tests become more troublesome. We report the first case of HIV/AIDS in children in East Java Province and its diagnostic and management problems.

\section{Report of the Case}

A 27 month old girl was admitted twice to the Dr. Sutomo Hospital. She was born uneventfully, assisted by a midwife, with a birth weight of $2800 \mathrm{~g}$, without evidence of asphyxia. She was cared by the midwife; her immunization status was up to date, she was breastfed for one year. The child began to walk, called 'papa' and 'mamma'. Since the age of one year, she had frequent episodes of cough and runny nose along with anorexia.

On December $10^{\text {th }}$ she had the first hospitalization with the main complaint of pallor, intermittent fever, and furuncles on the scalp. Physical examination on the first day of hospitalization revealed a twenty five month old girl, with a body weight of 9500 
g (87\% of modified NCHS), the temperature was $40^{\circ} \mathrm{C}$. She appeared anemic; there were furuncles on the scalp, especially on the temporal region and an abscess was evident along the neck.

Laboratory findings showed hemoglobin $5 \mathrm{~g} / \mathrm{dl}$, ESR 110/hour, normal platelet count, WBC 6.4X103/ $\mu \mathrm{l}$ with normal differential count. The albumin level was $2.8 \mathrm{~g} / \mathrm{dl}$, globulin $4.0 \mathrm{~g} / \mathrm{dl}$, normal urinalysis. Widal test and culture for $S$. typhi yielded negative results. Urine culture revealed Klebsiella species with a colony count more than 10.5 There was a normal picture of bone marrow aspiration. Serum iron was $45 \mathrm{mg} / \mathrm{dl}$, iron binding capacity $544 \mathrm{mg} / \mathrm{dl}$. Chest X-ray revealed a normal lung appearance with mild cardiomegaly.

The furuncles developed to abscess which were incised; antibiotic was given along with blood transfusion. She was discharged two weeks later (on December 24). She was advised to have a follow-up visit, but never showed up, until on the $20^{\text {th }}$ of January, she was hospitalized again. She had suffered from diarrhea for more than 2 weeks, developed furuncles again, and showed a rapid body wasting.

Physical examination revealed a severely malnourished child weighing only $7200 \mathrm{~g}$. She was alert, with furuncles on scalp and neck, rales on both lungs and there was evidence of thrush involving the mouth and vagina.

The hemoglobin content was $14.4 \mathrm{gr} / \mathrm{dl}$, WBC $2.5 \times 10^{3} / \mu 1$ with normal platelet count. The albumin was $3.4 \mathrm{~g} / \mathrm{dl}$. There was severe hypokalemia $(1.9 \mathrm{mEq} /$ $\mathrm{L})$, sodium was $126 \mathrm{mEq} / \mathrm{L}$. Stool examination was normal, urinalysis revealed albuminuria with plenty of leukocytes per visual field.

There was no BCG scar. Tuberculin (Mantoux test) showed negative result $(0 \mathrm{~mm})$, and the chest roentgenogram was normal. Her father was suspected for having tuberculosis in the lung. Blood culture yielded a negative result, urine culture revealed $E$. coli with a colony count exceeding $10^{5} / \mathrm{ml}$. Acid-fast bacilli did not grow from gastric washing. Antibiotics, vitamins, fungicide were given, and potassium chloride was added intravenously. Co-trimoxazole was added for the urinary tract infection. She continued giving loose stool 7-10 time a day, coughing and rapidly lost weight. Low lactose milk was given.

On the $4^{\text {th }}$ day of hospitalization, the condition worsened, cefotaxim of $200 \mathrm{mg} / \mathrm{kg} /$ day was added. Candidiasis persisted.
On the $10^{\text {th }}$ day, despite the normal temperature and improvement of the furunculosis, the diarrhea persisted, and the condition did not improve. The low lactose milk was changed to MCT, given as continuous feeding. As there was no response to local nystatin, fluconazole was given with a dose of $3 \mathrm{mg} / \mathrm{kg} / \mathrm{day}$. In spite of vigorous antimicrobial therapy, the infections seemed to persist and immune deficiency was considered. A more cautious and careful history was taken, which brought up new information such as a jobless father familiar with cocaine, a mother working at a massage parlor and suspected to be a commercial sexual worker beforehand. Both parents denied having had any blood transfusion or its component. With lots of difficulties, they finally approved the informed consent and HIV test (ELISA) was done on the patient and later on both parents. The HIV antibodies were confirmed on 3 consecutive tests using 3 different antigens on the patient as well as both parents. Lamivudine, cotrimoxazole, higher dose of fluconazole, cefotaxim and cloxacillin were instituted. More strict isolation and precaution were then implemented. Lamivudine was given as a single antiretroviral since no other drugs were available.

On day 17 the candidiasis persisted, the child became weaker, lymphocyte count was $24.1 \%$, other test such as CD4+ count, was not done. The more vigorous effort was less rewarding. Diarrhea persisted, the hemoglobin dropped, and the child suffered cough and fever. Wasting continued to manifest. Constraints had to be faced, both on running diagnostic tests to any suspicious infection as well as implementing the appropriate treatment, due to limited resources. We had to give more attention on antimicrobials and other drugs needed, so the CD4+ count and other laboratory monitoring measures were not done. On the other hand some laboratory examination were not available anymore, due to more expensive reagents or to their very special methods.

Ten days later, on the day 28, the child developed respiratory distress and passed away.

\section{Discussion}

The clinical manifestations of HIV in children vary widely, ranging from asymptomatic to severe sepsis or neoplasma. ${ }^{1-7}$ Most patients represent those of the impaired immune system. Opportunistic infections 
such as Pneumocystis carinii pneumonia with a long cough and fever, not responding to ordinary therapy should lead to the suspicion of HIV infection. ${ }^{7}$ Infected children usually suffer the common childhood infections more severe and more frequently than uninfected children. These bacterial infections can cause fever, pneumonia, recurrent cold, diarrhea, that often results in extended hospital stays and nutritional problems. Patients also frequently have severe candidiasis, resistant to ordinary treatment..$^{2-7}$

All patients should be assessed clinically and immunologically to classify and treat accordingly or predict whether the infection progressed to AIDS or not. After assessing the clinical signs and symptoms, one has to look for the seromarkers. ${ }^{7,8}$ Children born to mothers with positive HIV can give a positive seromarker test up to 18 months, due to the transplacental antibody transfer. After the age of 18 months, only the infected children will be positive for ELISA (Enzyme linked immuno assay), IFA (immunofluorencent assay) or HIV-1 antibody by Western Blot (WB). The PCR method can detect certain nucleotide (gp24 or viral DNA) of the virus, but since the test is special and expensive, they are not usually done. The Ministry of Health had released a substitute for Western Blot, using the Micro-Elisa HIV Uniform II plus, immunochromatography HIV I-II and Serodia agglutination. The positive test shows the presence of antibodies to several special proteins complementary. Positive tests on all of these three tests are regarded as positive HIV infection. ${ }^{7}$ Patient and her parents were positive for all these test. The revised definition of HIV infection classifies patients according three important parameters: i.e., infection status, clinical status and immunological status. They will reflects the stage of the child's disease, mutually exclusive classification and balances simplicity and accuracy. ${ }^{7,8,10}$

Our patient was more than 18 months of age, with HIV positive, wasting, chronic diarrhea, repeated fever, repeated skin infections, candidiasis, and chronic cough. The total lymphocyte count was $24.1 \%$, which is classified as intermediate suppression. As we assessed according to the 1994 revised HIV Pediatric Classification, the patient is classified as $\mathrm{C} 2$ category, with a severe clinical manifestation. ${ }^{8,11}$

She developed intermittent fever since the age of 1 year. Fever in patients with AIDS is nonspecific but mostly due to combined infections. Each fever episode should thoroughly be investigated, which was not done properly in our patient. There were negative Widal test, negative blood culture, and normal picture of blood smear with signs of urinary tract infection from the urinalysis and urine culture. The other sign of infection was the furuncles. Ordinary antibiotic had a limited effect.

Many HIV infected patients have lung disease that may manifest as acute Pneumocystis carinii pneumonia (PCP), as the slowly developing lymphoid interstitial pneumonitis (LIP) or as a nonspecific chronic lung disease. Children with lung involvement may develop cough with or without reactive airway. The patient present a chronic cough, which more likely resemble a LIP, whereas acute lung damage at the terminal stage may be due to acute PCP or cytomegalovirus pneumonia. $3,6,7,11$

The most common GI manifestations seen in HIV infected child are: (1) secondary opportunistic infection that interfere with the integrity of intestinal mucosa, such as cytomegalovirus infection, cryptosporidiosis, isosporiasis or Mycobacterium avium intracellular, bacterial infections. (2)intermittent obstruction of the intestinal adenopathy, (3) villous atrophy which may be a direct effect of HIV itself. The multitude of causes for malabsorption, chronic diarrhea, and subsequent malnutrition in HIV infection play a major role in progression of infection. ${ }^{8,10}$ They also limit the usefulness of oral medications given for the treatment of primary HIV and its complications. In this patient she developed chronic diarrhea without a positive lactase deficiency. The process might be due to parasitic/viral infection or due to direct effect of the HIV itself. $5,7,10$

Cardiac disease is most frequently recognized in HIV patients older than 2 years and manifests itself as a cardiomyopathy. Chronic cardiomyopathy and heart failure may contribute significantly to the patient's failure to thrive. ${ }^{3,6,7}$ This conditions was detected in this patients on the first hospitalization, which was mistaken as an anaemic cardiomegali.

Hematological abnormalities are also important. The anaemia may be due to the repeated blood loss through the intestine or urinary tract or due to the effect of HIV itself on the bone marrow. Transfusions are not enough, some may require high doses of IVGG for their thrombocytopenia. The anaemia, leukope- 
nia and thrombocytopenia may also be due to the repeated infections. ${ }^{2,7}$

Treatment and monitoring must be done with CD4+ counting. In this case the count had not been done since the reagent was not available. The total lymphocyte count is $24,1 \%$ which is classified as intermediate suppression. A severe clinical manifestation are not strictly related to the CD4+ count or total lymphocyte count, but also due to the combined and severity of the infections. ${ }^{8,10}$

The patient was treated with lamivudine only, since no antiretroviral drugs are available in the 'Jaring Pengaman Sosial' (Social Crisis Relieve) program. The limited resources were reserved for the antimocrobial and diagnostic test with high priority. Some diagnostic tests were not available any longer due to the shortage of hospital budget. CD4+ counting as one of treatment and monitoring criteria were not done. The shortages and limited funds were not the only factor, there were other factors such as unpreparedness and conceited attitude that posed a constraint to proper diagnosis and treatment. Anyhow the increasing tendency of clinical cases in East Java should be anticipated by a more aggressive preparedness of clinicians and its supporting back ups.

\section{References}

1. Borkowsky W, Wilfred CM. Acquired immmunodeficiency syndrome. In Krugman, Katz, Gershon and Wilfred (eds) Infectious diseases of children. $9^{\text {th }}$ ed. Philadelphia, Mosby\&Co, 1992; p.1-22.
2. Clebunder R, QuinnTh C. Retrovirus and the human immunodeficiency syndrome. In: Warren KS and Mahmoud AAF, editors. Tropical and geographical medicine, $2^{\text {nd }}$ ed, New York, Mac Graw-Hill; 1990. p. 728-40.

3. Yogev R, Chadwick EG. Acquired immunodeficiency syndrome (Human Immunodeficiency Virus) in Behrman RE, Kliegman RM, Jenson HB (eds). Nelson textbook of pediatric. $16^{\text {th }}$ ed, Philadelphia, WB Saunders; 2000:102232.

4. Udin M Muslaini, Arya Sidemen, Handari Yektiwi. Pemetaan risiko kabupaten/kota dan menu kegiatan penanggulangan AIDS propinsi Jawa Timur, KONAS IX Jaringan Epidemiologi Nasional, Jakarta, 2000.

5. Connor E, McSherry G, Yogev R. Antiviral therapy of pediatric HIV infection. In Yogev R and Connor E (eds). Management of HIV infections in infants and children, St. Louis, Mosby Year Book; 1992, p. 505-31.

6. Hanson CG, Shearer WT. Pediatric HIV and AIDS. In Feign RD and Cherry JD, editord. Textbook of pediatric infectious diseases. $3^{\text {rd }}$ ed, Philadelphia, WB Saunders, 1992. p. 990-1008.

7. Ministry of Health. Surat Edaran Dirjen PPM dan PLP. Pemeriksaan infeksi HIV, PL 00.08.4.53, July 29, 1996.

8. Hoyt. LG, Olske. JM. The clinical spectrum of infections in Infants and children: an overview. In Yogev R, Connor,E (eds) : Management of HIV infections in infants and children. St. Louis, Mosby Year Book; 1992. p.227.

9. CDC and P 1994 revised classification system for human immunodeficiency virus infection in children less than 13 years of age MMWR 1994; 43 (RR-12):1-10.

10. Seidel JS. Treatment of parasitic infections. Pediatr Clin North Am; 1985, 32:1077-95.

11. Nielsen K. Pediatric HIV infection: HIV Clinical management series, from http://pediatrics.medscape.com/ Medscape/HIV/ClinicalMgmt at 02/20/00. 